\title{
PENGARUH HASIL BELAJAR SISWA DENGAN MENGGUNAKAN MULTI MEDIA PEMBELAJARAN INTERAKTIF UNTUK SEKOLAH MENENGAH PERTAMA DAN SEKOLAH MENENGAH ATAS
}

\author{
Agung Wijoyo \\ Teknik Informatika, Universitas Pamulang \\ e-mail: dosen01671@unpam.ac.id
}

\begin{abstract}
ABSTRAK
Multimedia Interaktif adalah suatu media yang terdiri dari bayak komponen atau media yang terhubung satu sama lain dan mampu berinteraksi. Pengajaran media dalam bentuk multimedia interaktif memiliki kemampuan untuk menyimpan audio visual data, membuat multimedia interaktif khususnya interaktif pembelajaran sebagai pendukung metode pembelajaran konvensional yang dulu disampaikan melalui buku dan penjelasan langsung tanpa contoh dianggap kurang mudah dicerna oleh anak-anak, sehingga diharapkan pemanfaatan media interaktif yang bertujuan untuk meningkatkan hasil belajar dapat menjelaskan bahwa media pembelajaran interaktif mampu memberikan informasi dengan lebih menarik dan menyenangkan dari pada harus mendengarkan materi yang diberikan oleh pendidik. Seperti kita ketahui pelajaran Fisika merupakan momok bagian sebagian siswa-siswi SMP-SMA. Mereka sulit menyerap pelajaran Fisika karena guru sudah membebani siswa dengan rumus-rumus yang membuat siswa semakin pusing. Dengan Multimedia Pembelajaran Interaktif Fisika diharapkan para siswa dapat memahami konsepnya terlebih dahulu, sehingga siswa yang awalnya tidak menyukai pelajaran Fisika maka akan menyukai Pelajaran Fisika dan sekaligus dapat meningkatkan prestasi belajar.
\end{abstract}

Kata kunci: multimedia, audio, visual, interaktif, konsep, prestasi

\section{PENDAHULUAN}

Belajar merupakan proses perubahan dalam pikiran dan karakter intelektual anak didik, sedangkan pembelajaran adalah proses memfasilitasi siswa agar siswa belajar. Antara belajar dan pembelajaran merupakan satu kesatuan yang tidak terpisahkan (I Gede Astawan. Harian Bernas, 8 Agustus 2016).

Belajar dimaksud agar terjadinya perubahan dalam pikiran dan karakter diri siswa. Tantangan guru tidak hanya membekali ketrampilan siswa saat ini, tapi memastikan bahwa anak didik setelah belajar disekolah dapat terjun dimasyarakat. Untuk itu guru harus membekali ketrampilan siswa saat ini.

Pembelajaran Abad 21 memiliki perbedaan dengan pembelajaran di masa yang lalu. Dahulu pembelajaran dilakukan tanpa memperhatikan standard, sedang kini pembelajaran memerlukan standard sebagai acuan untuk mencapai tujuan pembelajaran. Melalui standard ang telah ditetapkan, guru mempunyai pedoman yang pasti tentang apa yang diajarkan dan yang hendak dicapai.

Kemajuan teknologi informasi dan komunikasi telah merubah gaya hidup manusia, baik dalam bekerja, bersosialisasi, bermain maupun belajar. Memasuki abad 21 kemajuan teknologi tersebut telah memasuki berbagai sendi kehidupan, tidak terkecuali dibidang pendidikan. Guru dan siswa, dosen dan mahasiswa, pendidik dan peserta didik dituntut memiliki kemampuan belajar mengajar di abad 21 ini. Sejumlah tantangan dan peluang harus dihadapi siswa dan guru agar dapat bertahan dalam abad pengetahuan di era informasi ini (Yana, 2013).

Pendidikan Nasional abad 21 bertujuan untuk mewujudkan cita-cita bangsa, yaitu masyarakat bangsa Indonesia yang sejahtera dan bahagia, dengan kedudukan yang terhormat dan setara dengan bangsa lain dalam dunia global, melalui pembentukan masyarakat yang terdiri dari sumber daya manusia yang berkualitas, yaitu pribadi yang mandiri, berkemauan dan berkemampuan untuk mewujudkan cita-cita bangsanya (BSNP, 2010).

\section{A. Konsep Belajar dan Pembelajaran Abad 21}

Untuk mengembangkan pembelajaran abad 21, guru harus memulai satu langkah perubahan yaitu merubah pola pembelajaran tradisional yang berpusat pada guru menjadi pola pembelajaran yang berpusat pada siswa. Pola pembelajaran yang tradisional bisa dipahami 
sebagai pola pembelajaran dimana guru banyak memberikan ceramah sedangkan siswa lebih banyak mendengar, mencatat dan menghafal.

Guru sudah sering mendengar mengenai pola pembelajaran CBSA (Cara Belajar Siwa Aktif), namun pendekatan yang dilakukan masih bersifat tradisional. Untuk mengerti pola pembelajaran yang berpusat pada siswa maka kita bisa kembali kepada slogan pendidikan kita yang tercantum dalam logo kementerian pendidikan dan kebudayaan dan merupakan pesan dari Bapak Pendidikan Bangsa, Ki Hajar Dewantara, yaitu Tut Wuri Handayani. Guru berperan sebagai pendorong dan fasilitator agar siswa bisa sukses dalam kehidupan. Satu hal lain yang penting yaitu guru akan menjadi contoh pembelajar (learner model), guru harus mengikuti perkembangan ilmu terakhir sehingga sebetulnya dalam seluruh proses pembelajaran ini guru dan siswa akan belajar bersama namun guru mempunyai tugas untuk mengarahkan dan mengelola kelas.

Untuk mampu mengembangkan pembelajaran abad 21 ini ada beberapa hal yang penting untuk diperhatikan yaitu antara lain :

1. Tugas Utama Guru Sebagai Perencana Pembelajaran.

Sebagai fasilitator dan pengelola kelas maka tugas guru yang penting adalah dalam pembuatan RPP. RPP haruslah baik dan detil dan mampu menjelaskan semua proses yang akan terjadi dalam kelas termasuk proses penilaian dan target yang ingin dicapai. Dalam menyusun RPP, guru harus mampu mengkombinasikan antara target yang diminta dalam kurikulum nasional, pengembangan kecakapan abad 21 atau karakter nasional serta pemanfaatan teknologi dalam kelas.

2. Masukkan unsur Berpikir Tingkat Tinggi (Higher Order Thinking)

Teknologi dalam hal ini khususnya internet akan sangat memudahkan siswa untuk memperoleh informasi dan jawaban dari persoalan yang disampaikan oleh guru.

Untuk permasalahan yang bersifat pengetahuan dan pemahaman bisa dicari solusinya dengan sangat mudah da nada kecenderungan bahwa siswa hanya menjadi pengumpul informasi. Guru harus mampu memberikan tugas di tingkat aplikasi, analisa, evaluasi dan kreasi, hal ini akan mendorong siswa untuk berpikir kritis dan membaca informasi yang mereka kumpulkan sebelum menyelasikan tugas dari guru.
3. Penerapan pola pendekatan dan model pembelajaran yang bervariasi

Beberapa pendekatan pembelajaran seperti pembelajaran berbasis proyek (Project Based Learning), pembelajaran berbasis keingintahuan (Inquiry Based Learning) serta model pembelajaran silang (jigsaw) maupun model kelas terbalik (Flipped Classroom) dapat diterapkan oleh guru untuk memperkaya pengalaman belajar siswa (Learning Experience). Satu hal yang perlu dipahami bahwa siswa harus mengerti dan memahami hubungan antara ilmu yang dipelajari di sekolah dengan kehidupan nyata, siswa harus mampu menerapkan ilmunya untuk mencari solusi permasalahan dalam kehidupan nyata. Hal ini yang membuat Indonesia mendapatkan peringkat rendah (64 dari 65 negara) dari nilai PISA di tahun 2012, siswa Indonesia tidak biasa menghubungkan ilmu dengan permasalahan riil kehidupan.

4. Integrasi Teknologi

Sekolah dimana siswa dan guru mempunyai akses teknologi yang baik harus mampu memanfaatkan teknologi dalam proses pembelajaran, siswa harus terbiasa bekerja dengan teknologi seperti layaknya orang yang bekerja. Seringkali guru mengeluhkan mengenai fasilitas teknologi yang belum mereka miliki, satu hal saja bahwa pengembangan pembelajaran abad 21 bisa dilakukan tanpa unsur teknologi, yang terpenting adalah guru yang baik yang bisa mengembangkan proses pembelajaran yang aktif dan kolaboratif, namun tentu saja guru harus berusaha untuk menguasai teknologinya terlebih dahulu.Hal yang paling mendasar yang harus diingat bahwasannya teknologi tidak akan menjadi alat bantu yang baik dan kuat apabila pola pembelajarannya masih tradisional.

\section{B. Prinsip Pokok Pembelajaran Abad 21}

Dalam buku paradigma pendidikan nasional abad XXI yang diterbitkan Badan Standar Nasional Pendidikan (BNSP) atau membaca isi Pemendikbud No. 65 tahun 2013 tentang Standar Proses, BSNP merumuskan 16 prinsip pembelajaran yang harus dipenuhi dalam proses pendidikan abad ke-21.

Sedangkan Pemendikbud No. 65 tahun 2013 mengemukakan 14 prinsip pembelajaran, terkait dengan implementasi Kurikulum 2013. 
Sementara itu, Jennifer Nichols menyederhanakannya ke dalam 4 prinsip pokok pembelajaran abad ke 21yang dijelaskan dan dikembangkan seperti berikut ini :

\section{Instruction should be student-centered} Pengembangan pembelajaran seyogyanya menggunakan pendekatan pembelajaran yang berpusat pada siswa. Siswa ditempatkan sebagai subyek pembelajaran yang secara aktif mengembangkan minat dan potensi yang dimilikinya. Siswa tidak lagi dituntut untuk mendengarkan dan menghafal materi pelajaran yang diberikan guru, tetapi berupaya mengkonstruksi pengetahuan dan keterampilannya, sesuai dengan kapasitas dan tingkat perkembangan berfikirnya, sambil diajak berkontribusi untuk memecahkan masalah-masalah nyata yang terjadi di masyarakat.

2. Education should be collaborative

Siswa harus dibelajarkan untuk bisa berkolaborasi dengan orang lain. Berkolaborasi dengan orang-orang yang berbeda dalam latar budaya dan nilai-nilai yang dianutnya. Dalam menggali informasi dan membangun makna, siswa perlu didorong untuk bisa berkolaborasi dengan teman-teman di kelasnya. Dalam mengerjakan suatu proyek, siswa perlu dibelajarkan bagaimana menghargai kekuatan dan talenta setiap orang serta bagaimana mengambil peran dan menyesuaikan diri secara tepat dengan mereka.

3. Learning should have context

Pembelajaran tidak akan banyak berarti jika tidak memberi dampak terhadap kehidupan siswa di luar sekolah. Oleh karena itu, materi pelajaran perlu dikaitkan dengan kehidupan sehari-hari siswa. Guru mengembangkan metode pembelajaran yang memungkinkan siswa terhubung dengan dunia nyata (real word). Guru membantu siswa agar dapat menemukan nilai, makna dan keyakinan atas apa yang sedang dipelajarinya serta dapat mengaplikasikan dalam kehidupan sehariharinya. Guru melakukan penilaian kinerja siswa yang dikaitkan dengan dunia nyata.

4. Schools should be integrated with society

Dalam upaya mempersiapkan siswa menjadi warga negara yang bertanggung jawab, sekolah seyogyanya dapat memfasilitasi siswa untuk terlibat dalam lingkungan sosialnya. Misalnya, mengadakan kegiatan pengabdian masyarakat, dimana siswa dapat belajar mengambil peran dan melakukan aktivitas tertentu dalam lingkungan sosial. Siswa dapat dilibatkan dalam berbagai pengembangan program yang ada di masyarakat, seperti: program kesehatan, pendidikan, lingkungan hidup, dan sebagainya. Selain itu, siswa perlu diajak pula mengunjungi panti-panti asuhan untuk melatih kepekaan empati dan kepedulian sosialnya.

\section{Model Pembelajaran dan Peran Pendidik Abad} 21.

Ada beberapa model pembelajaran yang layak untuk diaplikasikan dalam pembelajaran abad 21. Namun yang paling populer dan banyak di implementasikan adalan model Pembelajaran PjBL (Project Based Learning dan Inquiry Based Learning)

1) $\mathrm{PjBL}$ atau Pembelajaran Berbasis Proyek merupakan model belajar yang menggunakan masalah sebagai langkah awal dalam mengumpulkan dan mengintegrasikan pengetahuan baru berdasarkan pengalamannya dalam beraktivitas secara nyata. Pembelajaran Berbasis Proyek dirancang untuk digunakan pada permasalahan komplek yang diperlukan peserta didik dalam melakukan insvestigasi dan memahaminya. Melalui PjBL, proses inquiry dimulai dengan memunculkan pertanyaan penuntun (a guiding question) dan membimbing peserta didik dalam sebuah proyek kolaboratif yang mengintegrasikan berbagai subjek (materi) dalam kurikulum. Pada saat pertanyaan terjawab, secara langsung peserta didik dapat melihat berbagai elemen utama sekaligus berbagai prinsip dalam sebuah disiplin yang sedang dikajinya. PjBLmerupakan investigasi mendalam tentang sebuah topik dunia nyata, hal ini akan berharga bagi atensi dan usaha peserta didik.

Mengingat bahwa masing-masing peserta didik memiliki gaya belajar yang berbeda, maka Pembelajaran Berbasis Proyek memberikan kesempatan kepada para peserta didik untuk menggali konten (materi) dengan menggunakan berbagai cara yang bermakna bagi dirinya, dan 
melakukan eksperimen secara kolaboratif. Pembelajaran Berbasis Proyek merupakan investigasi mendalam tentang sebuah topik dunia nyata, hal ini akan berharga bagi atensi dan usaha peserta didik.

Pembelajaran Berbasis Proyek dapat dikatakan sebagai operasionalisasi konsep "Pendidikan Berbasis Produksi" yang dikembangkan di Sekolah Menengah Kejuruan (SMK). SMK sebagai institusi yang berfungsi untuk menyiapkan lulusan untuk bekerja di dunia usaha dan industri harus dapat membekali peserta didiknya dengan "kompetensi terstandar" yang dibutuhkan untuk bekerja pada bidang masing-masing. Dengan pembelajaran "berbasis produksi" peserta didik di SMK diperkenalkan dengan suasana dan makna kerja yang sesungguhnya di dunia kerja.

2) Inquiry Based Learning

Kata "Inquiry" berasal dari Bahasa Inggris yang berarti mengadakan penyelidikan, menanyakan keterangan, melakukan pemeriksaan (Echols dan Hassan Shadily, 2003: 323). Sedangkan menurut Gulo (2005:84) inkuiri berarti pertanyaan atau pemeriksaan, penyelidikan. Di dalam inquiry terdapat keterlibatkan siswa untuk menuju ke pemahaman. Lebih jauh disebutkan bahwa keterlibatan dalam proses belajar akan berdampak pada perolehan keterampilan dan sikap yang diperlukan untuk pemecahan masalah, yakni menemukan jawaban dari pertanyaan yang selanjutnya digunakan untuk membangun pengetahuan baru bagi siswa.

Inquiry didefiniskan sebagai usaha menemukan kebenaran, informasi, atau pengetahuan dengan bertanya. Seseorang melakukan proses inquiry dimulai ketika lahir sampai dengan ketika meninggal dunia. Proses inquiry dimulai dengan mengumpulkan informasi dan data melalui pancaindera yakni penglihatan, pendengaran, sentuhan, pencecapan, dan penciuman.

Pendekatan IBL adalah suatu pendekatan yang digunakan dan mengacu pada suatu cara untuk mempertanyakan, mencari pengetahuan (informasi), atau mempelajari suatu gejala.

Pembelajaran dengan pendekatan IBL selalu mengusahakan agar siswa selalu aktif secara mental maupun fisik. Materi yang disajikan guru bukan begitu saja diberitahukan dan diterima oleh siswa, tetapi siswa diusahakan sedemikian rupa sehingga mereka memperoleh berbagai pengalaman dalam rangka "menemukan sendiri" konsep-konsep yang direncanakan oleh guru.

Inquiry based learning adalah sebuah teknik mengajar di mana guru melibatkan siswa di dalam proses belajar melalui penggunaan cara-cara bertanya, aktivitas problem solving, dan berpikir kritis. Hal ini akan memerlukan banyak waktu dalam persiapannya.

Inquiry based learning biasanya berupa kerja kolaboratif. Kelas dibagi ke dalam kelompok-kelompok kecil. Setiap kelompok diberi sebuah pertanyaan atau permasalahan yang akan mengarahkan semua anggota kelompok bekerja bersama mengembangkan proyek berdasarkan pertanyaan tersebut untuk menemukan jawabannya. Karena inquiry-based learning berbasis pertanyaan, maka guru harus menyiapkan pertanyaan yang bersifat terbuka sehingga siswa dapat mengembangkan pikirannya. Siswa harus diberi kesempatan untuk mencoba menemukan sendiri konsep yang diajarkan. Lebih dari itu, jika siswa juga diberi kesempatan untuk mengukur kemajuan belajarnya sendiri, maka hal ini akan membantu mereka belajar.

\section{Peran Pendidik}

Pendidik berperan sangat penting, karena sebaik apa pun kurikulum dan sistem pendidikan yang ada, tanpa didukung mutu pendidik yang memenuhi syarat maka semuanya akan sia-sia. Sebaliknya, dengan pendidik yang bermutu maka kurikulum dan sistem yang tidak baik akan tertopang. Keberadaan pendidik bahkan tak tergantikan oleh siapapun atau apapun sekalipun dengan teknologi canggih. Alat dan media pendidikan, sarana prasarana, multimedia dan teknologi hanyalah media atau alat yang hanya digunakan sebagai rekan dalam proses pembelajaran.

Oleh karena itu, pendidik dan tenaga kependidikan perlu memiliki kualifikasi yang dipersyaratkan, kompetensi yang terstandar serta mampu mendukung dan menyelenggarakan pendidikan secara profesional. Khususnya guru sangat menetukan kualitas output dan outcome yang dihasilkan oleh sekolah karena dialah yang 
merencanakan pembelajaran, menjalankan rencana pembelajaran yang telah dibuat sekaligus menilai pembelajaran yang telah dilakukan (Baker\&Popham, 2005:28).

Selain itu, menurut Nasution (2005:77) bahwa pendidik merupakan orang yang paling bertanggung jawab untuk menyediakan lingkungan yang paling serasi agar terjadi proses belajar yang efektif. Dengan demikian, apabila pedidik melaksanakan fungsi dan tugasnya dengan baik maka output yang dihasilkan akan baik. Sebaliknya, apabila pendidik tidak menjalankan tugas dan fungsinya dengan baik maka output yang dihasilkan tidak akan berkualitas.

Hal senada juga dikemukakan oleh Yulianto (2006:1), pendidik merupakan salah satu faktor kunci yang ikut menentukan arah kualitas pendidikan. Peran pendidik tidak bisa dihilangkan begitu saja. Apalagi, pendidik bukan semata-mata hanya mengajar tetapi dia juga mendidik. Sebagai pengajar, pendidik tidak hanya berperan dalam menyampaikan ilmu tapi juga berkewajiban melakukan evaluasi, mengelola kelas, mengembangkan perangkat pembelajaran dll.

Selain itu, Samani (1996) mengemukakan empat prasyarat agar seorang pendidik dapat profesional.

Masing-masing adalah :

1. Kemampuan mengolah/menyiasati kurikulum,

pendidik

2. Kemampuan pendidik mengaitkan materi kurikulum dengan Iingkungan,

3. Kemampuan pendidik memotivasi siswa untuk belajar sendiri dan

4. Kemampuan pendidik untuk mengintegrasikan berbagai bidang studi/mata pelajaran menjadi kesatuan konsep yang utuh.

Selanjutnya menurut Djojonegoro (1996) pendidik yang bermutu paling tidak memiliki empat kriteria utama, yaitu:

1. Kemampuan profesional, upaya profesional, waktu yang dicurahkan untuk kegiatan profesional dan kesesuaian antara keahlian dan pekerjaannya. Kemampuan profesional meliputi kemampuan intelegensi, sikap dan prestasi kerjanya.

2. Upaya profesional, adalah upaya seorang pendidik untuk mentransformasikan kemampuan profesional yang dimilikinya ke dalam tindakan mendidik dan mengajar secara nyata.
3. Mampu memanajemen waktu. Waktu, yang dicurahkan untuk kegiatan profesional menunjukkan intensitas waktu dari seorang pendidik yang dikonsentrasikan untuk tugas-tugas profesinya.

4. Dapat membelajarkan siswa secara tuntas, benar dan berhasil. Untuk itu pendidik harus menguasai keahliannya, baik dalam disiplin ilmu pengetahuan maupun metodologi mengajarnya.

Proses pembelajaran merupakan hal yang penting bagi manusia, dengan meningkatnya kesadaran akan manfaat dari ilmu dan pengetahuan yang dipelajari.

Objek pembelajaran berbasiskan multimedia mulai diterapkan sebagai salah-satu penunjang proses belajar mengajar. Saat ini, instansi pendidikan juga menerapkan pembelajaran dengan menggunakan multimedia interaktif untuk mempresentasikan bahan ajar kepada siswa didiknya, dalam bentuk multimedia interaktif untuk mempresentasikan bahan ajar kepada siswa didiknya, dalam bentuk Lab Virtual yang berisikan content digital.

Dasar pemikiran pada penelitian ini menyangkut pada siswa yang kurang berminat mempelajari pelajaran Fisika.

Maka berdasarkan permasalahan diatas, perlu dilakukan penelitian untuk mencari tahu kurangnya minat belajar siswa SMP-SMA terhadap pelajaran Fisika.

\section{MULTIMEDIA}

Multimedia merupakan kombinasi teks, foto, grafis, audio, animasi dan elemen video yang diolah secara digital [1]. Kombinasi beberapa unsur multimedia yang diolah sedemikian rupa, biasanya digunakan untuk tujuan tertentu, dimana dalam penelitian ini, multimedia diberlakukan sebagai objek pembelajaran (learning object), dalam bentuk materi pembelajaran Interaktif, terutama digunakan oleh siswa SMP-SMA.

Multimedia mempunyai beberapa karakteristik dasar, yaitu merupakan sistem yang dikontrol oleh komputer, informasi yang direpresentasikan secara digital, terintegrasi dan bersifat interaktif [2]. Oleh karena karakteristik itulah sebuah sistem berbasis multimedia layak dipertimbangkan sebagai sebuah format yang bisa digunakan untuk proses pembelajaran.

Penggunaan multimedia sebagai sebuah format untuk bahan pembelajaran interaktif kini 
telah diterapkan diberbagai sekolah. Inovasi teknologi berbasis digital elektronik secara radikal telahmengubah bidang pendidikan [3]. Hal ini bisa dilihat dari perubahan-perubahan yang terjadi pada bidang pendidikan beberapa tahun ke belakang. Bila dahulu seorang guru memberikan materi yang harus ditulis melalui papan tulis. Kini alat bantu seperti komputer telah mempermudah pekerjaan seorang pengajar/pendidik untuk menyusun materi pembelajaran dalam bentuk presentasi digital multimedia yang telah rancang dan dibuat terlebih dahulu pada software komputer.

Perkembangan teknologi, membuat konten pembelajaran yang inovatif dan menarik adalah sebuah tantangan tersendiri bagi profesi sebagai guru dan tenaga pengajar lainnya, termasuk pekerjaan-pekerjaan yang membutuhkan interaksi sosial antara seorang pengemuka pendapat (ide), terhadap audience nya, terutama akan sangat berguna saat melakukan penetrasi ide, dalam bentuk presentasi. Hal ini tentu saja membutuhkan sumber daya pengajar yang juga terlatih dan mahir dalam pembuatan materi pembelajaran secara komputerisasi dan digital. Dengan kata lain, sudah seharusnya saat sekarang ini, seseorang yang berprofesi sebagai tenaga pengajar harus mengikuti perkembangan teknologi informasi.

Pada abad ke-21, Multimedia adalah sebuah keterampilan dasar yang sama pentingnya dengan keterampilan membaca[4]. Hal ini bisa dibuktikan dengan perkembangan teknologi dan maraknya berbagai macam gadget canggih yang juga bisa mebuka file multimedia layaknya ebook atau buku digital dan pemutar video / musik secara portable dimana saja. Perkembangan teknologi saat ini, tentu saja bisa menjadi daya saing tersendiri bagi instansi pendidikan dan pengembang konten multimedia dalam bidang edukasi, terutama dalam pembuatan materi pembelajaran digital yang memungkinkan siswa belajar secara aktif dimanapun mereka berada.

\section{KOMPONEN MULTIMEDIA}

Multimedia merupakan sebuah kombinasi dari berbagai macam elemen yang dipadupadankan kedalam sebuah bentuk aplikasi presentasi yang interaktif. Beberapa elemen atau unsur yang terkandung dalam multimedia, antara lain Teks, Grafis/Foto, Audio, Video dan Animasi.

Teks merupakan elemen multimedia yang sangat penting, dengan adanya teks, sebuah informasi dapat dideskripsikan menjadi bentuk kalimat yang tertulis, dan bisa menjelaskan sesuatu hal dengan konten tulisan yang dapat dibaca. Dalam penyusunan multimedia, elemen teks yang digunakan adalah dengan cara mengetikan tipe Font dari Typeface yang ada kedalam workspace / layar. Sedangkan menurut Ref. [4] pengertian font sendiri, merupakan kumpulan karakter dari satu ukuran dan jenis yang dimiliki oleh keluarga typeface tertentu, dimana Typeface merupakan keluarga dari karakter grafis yang menyertakan banyak ukuran dan jenis. Grafis image merupakan elemen multimedia yang dapat menampilkan visualisasi dalam bentuk gambar, chart, dan foto yang fungsinya digunakan sebagai unsur penjelas dari konten multimedia[5].

Fungsi audio bagi learning object dalam multimedia interaktif, salah satunya adalah dapat memberikan informasi dalam bentuk suara yang dapat didengar oleh user.Saat ini komputer telah mampu untuk memutar dan mengkonversi suara analog menjadi format digital, yang bisa didengarkan pada berbagai benda elektronik. Dalam jenis format Audio digital pengubahan suara analog menjadi suara digital membutuhkan suatu alat yang disebut Analog to Digital Converter (ADC), dimana ADC ini akan mengubah amplitudo sebuah gelombang, yaitu dari analog, kedalam interval (sample) sehingga menghasilkan representasi digital dari suara [4].

Video merupakan sebuah pergerakan gambar yang konsisten dan telah diatur kecepatan geraknya[5], hal ini diperuntukan, agar tampilnya sebuah gambar bergerak yang dapat ditangkap oleh mata manusia.

Kebanyakan video juga mengandung unsur audio atau penyuaraan, dimana singkronisasi antara audio dengan video bisa menghasilkan sebuah pengalaman unik, dibandingkan dengan unsur multimedia lain.

Animasi merupakan sebuah tampilan gambar atau objek bergerak yang disusun berdasarkan sequence [5].

Animasi digunakan untuk memberikan unsur interaktivitas dalam konten multimedia seperti button (tombol), slideshow gambar/foto, Transisi halaman / slide, dan lainnya. Selain sebagai elemen interaktif fungsi pemberian unsur animasi dalam learning object berbasis multimedia, tak lain adalah sebagai penarik perhatian user.

\section{IDENTIFIKASI KOMPONEN MULTIMEDIA}

Setelah melalui studi literatur bisa dipaparkan dalam penilitian ini, bahwa 
kompleksitas komponen Multimedia yang digunakan sebagai learning object, apakah telah dapat mempercepat pemahaman siswa terhadap objek pembelajaran, dikarenakan kombinasi komponen Multimedia, yaitu; teks, grafis,audio, video, animasi dan link, sama sekali belum memiliki pedoman atau acuan umum untuk dimasukan sebagai learning object multimedia yang terstandarisasi pada instansi pendidikan, , meskipun sampai saat ini, multimedia telah digunakan sebagai alat bantu dan bahan ajar untuk guru atau pendidik.

\section{A. Generasi Buku Digital}

Saat ini untuk buku digital sudah masuk kedalam Generasi ke Empat.

\section{Generasi ke 1}

Dalam Generasi ini hanya berupa text atau gambar yang hanya di scanner dan formatnya hanya pdf, jpeg atau bmp. Pada generasi kita hanya bisa melihat saja.

Generasi ke 2

Dalam Generasi ini selain bentuk teks sudah mulai disipkan video. Untuk tampilan Video kita juga hanya bisa melihat saja.

\section{Generasi Ke 3}

Dalam Generasi ini sudah mulai disisipkan animasi dan hyperlink interactive.

Dalam hyperlink interaktif disini menggunakan flash dimana hasilnya belum maksimal di tambah Adobe akan menghapus Flash.

\section{Generasi ke 4}

Dalam Generasi yang terakhir dan penggunaan multimedia terbaru, dimana text, animasi, video sudah menyatu dan interaktif dimana sudah menggunakan html5.

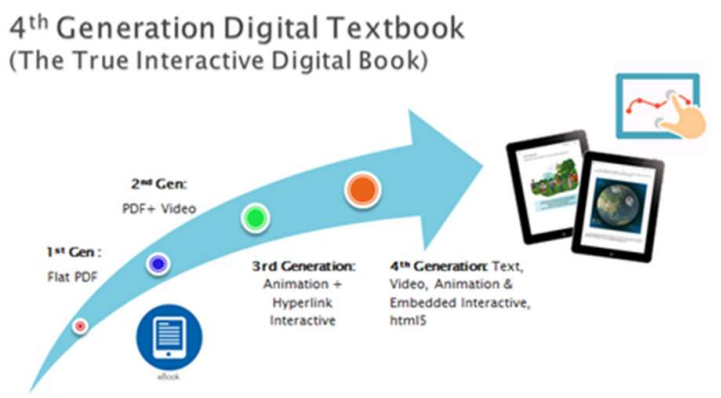

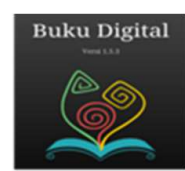

\section{4th Generation Interactive}
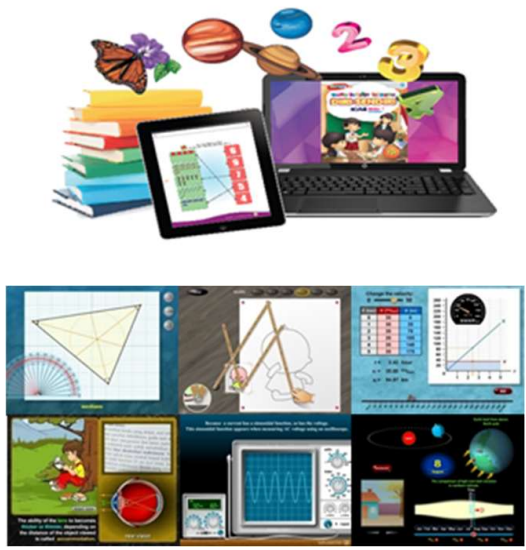

Gambar 1 Generasi Buku Digital

\section{METODE}

\section{KAJIAN STUDI LEARNING OBJECT MULTIMEDIA}

Beberapa penelitian tentang learning object berbasis multimedia telah dilakukan oleh para peneliti sebelumnya, menurut Ref. [6] dalam penelitiannya mengemukakan hasil, bahwa multimedia bisa digunakan untuk mengoptimalkan cognitive load, atau daya kognitif terhadap materi pembelajaran terhadap siswa.

Dalam penggunaan learning object berbasis multimedia, menurut Ref. [7] pada hasil penelitiannya menyatakan bahwa, meski beragam teknologi yang berbeda bisa diterapkan pada learning object multimedia, penyusunan yang baik bisa menjadikan objek pembelajaran lebih menarik dan dapat diingat lebih baik oleh user yang menggunakannya.

Sedangkan menurut Ref. [8] dari hasil penelitiannya mengenai penggunaan multiple information source dalam learning object mendapatkan 2 hasil, yaitu pertama pemanfaatan objek pembelajaran dari berbagai macam sumber pada akhirnya akan dihadapai oleh pelajar saat ini. Dan yang kedua, pada situasi dari banyaknya sumber informasi yang bisa dijadikan objek pembelajaran, perlu dilakukan penelitian lain tentang bagaimana menyelesaikan masalah tersebut. Dengan banyaknya unsur atau komponen Multimedia yang bisa diterapkan pada objek pembelajaran saat ini, perlu diketahui 
komponen apa saja yang sebenarnya bisa diterapkan pada learning object secara baik.

\section{KERANGKA PIKIR}

Setelah melalui studi literatur bisa dipaparkan dalam penilitian ini, bahwa kompleksitas komponen multimedia yang digunakan sebagai learning object, apakah telah dapat mempercepat pemahaman siswa terhadap objek pembelajaran, dikarenakan kombinasi komponen multimedia, yaitu; teks, grafis, audio, video, animasi dan hyperlink, sama sekali belum memiliki pedoman atau acuan umum untuk dimasukan sebagai learning object yang terstandarisasi pada instansi pendidikan, meskipun sampai saat ini, multimedia telah digunakan sebagai alat bantu dan bahan ajar untuk siswa.

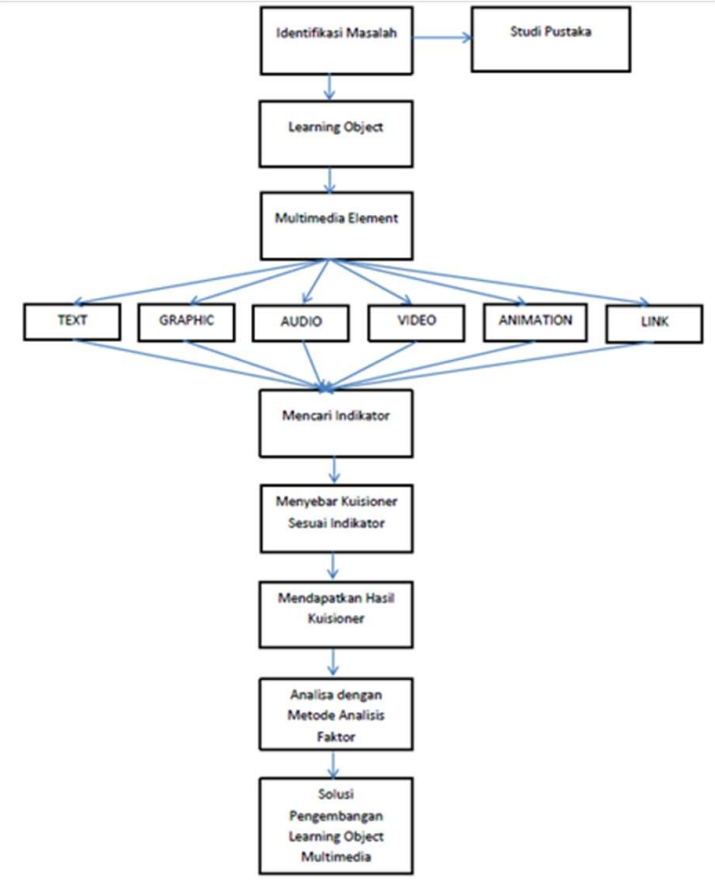

Gambar 2 Kerangka Pikir Learning Object Multimedia

Setelah indikator yang dicari pada setiap komponen multimedia ditemukan, maka akan disusun dan disebarkan kuisioner berdasarkan indikator-indikator tersebut, guna mengetahui perspektif dari jawaban para responden untuk digunakan analis faktor.

\section{UNSUR-UNSUR LEARNING OBJECT MULTIMEDIA FAKTOR/ELEMEN}

Teks : berisikan teks berupa kata-kata yang membentuk kalimat.
Grafis : berisikan ilustrsi gambar, chart, foto

Audio : berisikan audio yang mengandung bunyi (suara), musik atau narasi yang dapat didengar.

Video : berisikan gambar bergerak (movie) yang bisa dilihat.

Animasi : berisikan animasi yang dapat bergerak.

Link navigasi (hyperlink) : berisikan tampilan antar muka (user interface) yang bisa dinavigasikan ke internal link.

\section{HASIL DAN PEMBAHASAN}

Dalam penelitian ini, untuk mendapatkan respon siswa terhadap learning object yang digunakan, penulis turut serta membagi butir pertanyaan pada kuesioner dengan analisa fakta. 3 dimensi analisa fakta ini bersumber dari latar belakang masalah yang ada dalam pembuatan Learning object pada instansi pendidikan tingkat SMP dan SMA, 3 dimensi tersebut adalah :

a. Pertama adalah attention/attract atau tahapan awal yang membuat seseorang menjadi merasa tertarik akan atau tahapan awal yang membuat seseorang menjadi merasa tertarik akan sesuatu hal. Dalam konten penelitian ini adalah bahan materi ajar dalam bentuk Multimedia digital.

$b$. Kedua adalah interest, merupakan tahapan yang lebih dalam dari sekedar ketertarikan seseorang terhadap sesuatu hal, pada tahap interest, seseorang berarti juga memiliki minat terhadap hal yang disuguhkan yaitu learning object yang digunakan.

c. Ketiga understanding, yang merupakan tahapan pada dimensi paling dalam, dimana seseorang telah melalui tahapan tertarik, berminat menggunakan, hingga memikili pemahaman dari penggunaan learning object multimedia. Tujuan dari pembagian dimensi ini adalah untuk mengetahui:

1) Ketertarikan siswa pada learning object multimedia.

2) Minat siswa terhadap learning object multimedia.

3) Pemahaman siswa terhadap learning object multimedia.

\section{ANALISA FAKTOR}

Apabila dilihat dari 3 rata-rata tertinggi untuk keseluruhan indikator, maka indikator 
yang paling penting mempengaruhi learning object multimedia terhadap 3 Dimensi Analisa Fakta adalah :

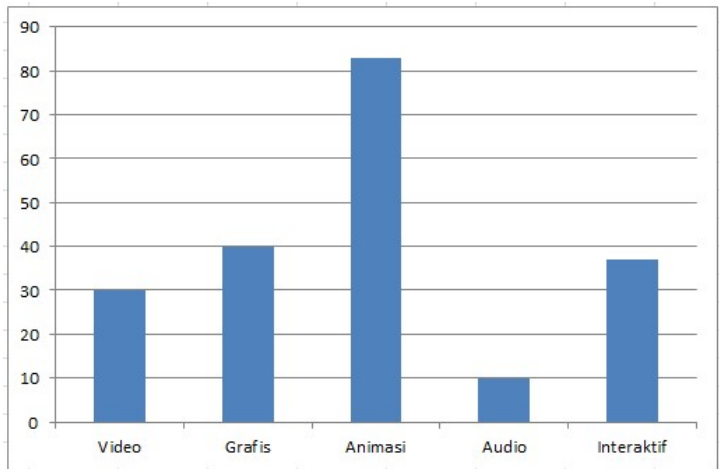

Gambar 3 Analisis Faktor Learning Object Multimedia berdasarkan ketertarikan

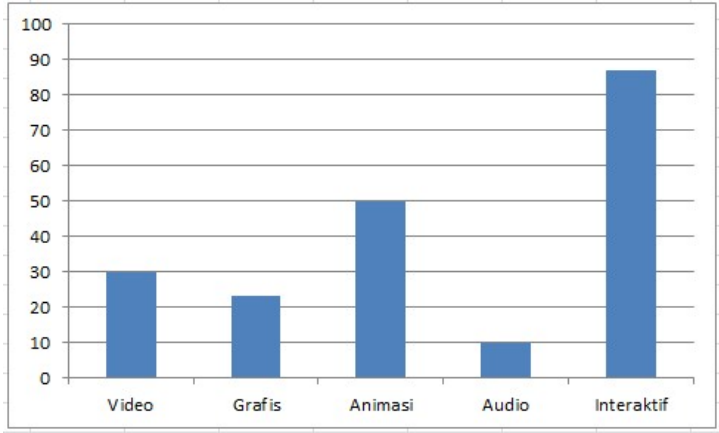

Gambar 4 Analisis Faktor Learning Object Multimedia berdasarkan Minat

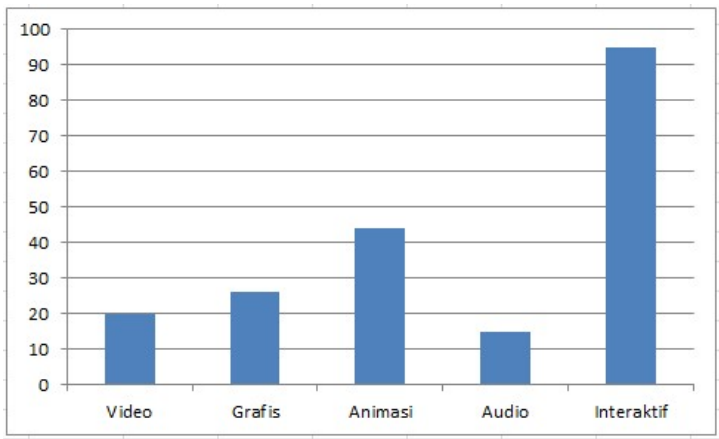

Gambar 5 Analisis Faktor Learning Object Multimedia berdasarkan Pemahaman

Dari keseluruhan dimensi yang ada yaitu: ketertarikan, minat dan pemahaman berdasarkan data yang didapat, maka dapat diinterprestasikan.

Untuk dimensi Ketertarikan, siswa sangat menyukai komponen animasi sebagai daya tarik.
Untuk dimensi Minat, siswa dapat sangat menyukai komponen interaktif sehimgga dapatmemahami konsep lebih mudah

Untuk dimensi Pemahaman, siswa dapat sangat menyukai komponen interaktif sehimgga dapatmemahami konsep lebih mudah

\section{KESIMPULAN}

Unsur animasi interaktif pada Learning object multimedia menjadi faktor yang paling mempengaruhi ketertarikan siswa terhadap sebuah objek pembelajaran digital. Sedangkan komponen Video yang biasanya berbentuk screen cast, , menjadi faktor yang mempengaruhi pemahaman. Dan komponen visual grafis merupakan faktor yang berpengaruh terhadap minat siswa dalam penggunaan learning object multimedia.

Visual Naration mewakili pengunaan gambar, illustrasi dan chart, sebagai elemen visual yang dikombinasikan dengan audio berserta narasi sebagai elemen penjelas. Dengan mengkombinasikan kedua elemen ini menjadi sebuah faktor, maka akan didapati sebuah learning object multimedia yang tidak hanya menarik, juga memberikan komponen dalam bentuk audio, sebagai elemen pemberi kejelasan pada materi pembelajaran.

\section{SARAN}

Setiap pendidik diharapkan dapat menguasasi beberapa multimedia pembelajaran agar dalam penyajian materi tidak membosankan, sehingga peserta didik dapat lebih aktif dalam memberikan tanggapan dan juga mendorong peserta didik untuk melakukan praktek-praktek dengan benar.

Pemilihan Multi Media Pembelajaran sebaiknya disesuaikan dengan materi yang diajarkan serta dikemas menjadi uraian pendek, pokok-pokok pembahasan atau pointer-pointer

\section{UCAPAN TERIMA KASIH}

Terima kasih atas dukungan baik wewenang maupun dana sehingga penelitian ini dapat terlaksana kepada :

- PesonaEDU Group

- PesonaEDU Creation

- PesonaEDU Solution 3

- PT. Citra Pesona Gemilang

\section{DAFTAR PUSTAKA}

[1]. Vaughan, T, "Multimedia: Making It Work, Sixth Edition", Appleton: McGraw-Hill Companies, inc, 2004, ch. 1, pp. 5-15. 
[2]. Marshall,D, "Introduction to Multimedia", Retrieved 7 12, 2009, from www.cs.cf.ac.uk : http://www.cs.cf.ac.uk/Dave/Multimedia/node1. html . 2001,7,12

[3]. Jenkinson, J, "Measuring the Effectiveness of Educational Technology", Electronic Journal of e-Learning Volume7 Issue3, 273 .2009.

[4]. Binanto, I, "Multimedia Digital : Dasar Teori dan Pengembangannya", Yogyakarta : Penerbit Andi, 2010,pp-2-18.

[5]. Selly \& Vermaat, "Discovering Computer 2010 : Living in a Digital World", Boston, USA : Course Technology, 2010,pp.93-96 